УДК 37.04

\title{
МЕДИАЦИЯ И МЕДИАТИВНЫЙ ПОДХОД КАК НОВАЯ ОБРАЗОВАТЕЛЬНАЯ ТЕХНОЛОГИЯ: ПЕРСПЕКТИВЫ РАЗВИТИЯ
}

\author{
Вечерина Ольга Павловна \\ кандидат исторических наук \\ доцент кафедры медиации в социальной сфере \\ ФГБОУ ВО «Московский государственный \\ психолого-педагогический университет»
}

Аннотация: в статье рассмотрены новые отечественные технологии работы с конфликтами и спорами в образовательной среде, разработанные на базе медиации. Опыт их внедрения показывает, что необходима дальнейшая теоретическая и практическая работа по совершенствованию подготовки школьных медиаторов на основе деятельностного подхода, разработанного российскими психологами, и теории медиации А. С. Ахиезера.

Ключевые слова: медиация, медиативный подход, теория медиации, школьная медиация, гражданское общество.

\section{MEDIATION AND MEDIATIVE APPROACH AS A NEW EDUCATIONAL TECHNOLOGY: DEVELOPMENT PROSPECTS}

\section{Vecherina Olga Pavlovna}

\begin{abstract}
The article discusses new domestic technologies for dealing with conflicts and disputes in the educational environment, developed on the basis of mediation. The experience of their implementation shows that further theoretical and practical work is needed to improve the training of school mediators on the basis of the activity approach developed by Russian psychologists and the theory of mediation by A.S. Akhiezer.
\end{abstract}

Key words: mediation, mediation approach, theory of mediation, school mediation, civil society.

Медиация как технология альтернативного разрешения споров впервые появилась в России как один из проектов, направленных на реформирование 


\section{ОБРАЗОВАТЕЛЬНЫЕ ТЕХНОЛОГИИ В СОВРЕМЕННОМ УЧЕБНО-ВОСПИТАТЕЛЬНОМ ПРОСТРАНСТВЕ}

российской судебной системы и развитие гражданского общества в связи с развитием деятельности первых НКО в начале 1990-х годов. Новые модели в целом не вписались в структуру российского социума, однако первые специалисты-медиаторы появились. Первоначально они работали в рамках конфликтологии, которая как научная дисциплина также появилась в России только в это время (СПбГУ).

Новый импульс, завершившийся принятием федерального закона от 27.07.2010 № 193-Ф3 «Об альтернативной процедуре урегулирования споров с участием посредника (процедуре медиации)», был дан на Первой международной конференции по медиации, проведенной в феврале 2005 г. В апреле того же года был создан Центр медиации и права (Ц.А. Шамликашвили), который стал одним из основных лоббистов институционального оформления медиации.

Практически одновременно приказом Министерства образования и науки РФ была утверждена Федеральная программа подготовки медиаторов, которая стала фундаментом для создания многочисленных центров по их подготовке, включая программы по медиации в ряде высших учебных заведений [1]. В декабре 2014 г. Министерством труда и социальной защиты был утвержден профессиональный стандарт «Специалист в области медиации» [2].

Одним из наиболее активных участников процесса развития медиации в России был виднейший российский юрист В.Ф. Яковлев, который полагал, что медиацию надо в первую очередь «рассматривать как один из способов формирования гражданского общества, она сопряжена с формированием подлинных институтов гражданского общества, в рамках которых и реализуются такие ценности, как свобода граждан, утверждение начал справедливости и безопасности» [2, с. 14].

Период 2010-2019 гг. можно охарактеризовать как первую фазу развития института медиации в России, когда была сделана попытка его внедрения именно как правового, а не социального института. Подводя итоги этой имплементации, авторы учебника «Альтернативное разрешение споров» под ред. проф. Е.А. Борисовой (2019) справедливо пишут: «Последствия такого подхода известны: процедура медиации практически не востребована гражданами и организациями» [4]. Этапы этого процесса, в том числе применительно к образовательной сфере, описаны нами в статьях [5] [6].

В настоящее время можно констатировать, что только школьная медиация и/или восстановительная медиация являются понятной и хорошо 


\section{ОБРАЗОВАТЕЛЬНЫЕ ТЕХНОЛОГИИ В СОВРЕМЕННОМ УЧЕБНО-ВОСПИТАТЕЛЬНОМ ПРОСТРАНСТВЕ}

проработанной траекторией как институционального, так и персонального профессионального развития в этой сфере, тогда как в остальных сферах применения процедура медиации пока продолжает оставаться мало востребованной.

Мы полагаем, что успехи школьной медитации стали возможными потому, что в образовательной сфере медиация развивалась как социальный институт и, в первую очередь, как новая образовательная технология. Такое развитие стало возможным благодаря развитию и имплементации отечественной концепции школьной медиации и тесно связанного с ней медиативного подхода. Нормативное определение медиативного подхода было дано в письме Министерства образования и науки Российской Федерации от 18 ноября 2013 г. № ВК-844/07 и в Распоряжении Правительства Российской Федерации от 30 июля 2014 г. № 1430-p: «Медиативный подход деятельностный подход, основанный на принципах медиации, предполагающий владение навыками позитивного осознанного общения, создающими основу для предотвращения и (или) эффективного разрешения споров и конфликтов в повседневных условиях без проведения медиации как полноценной процедуры. Медиативный подход может использоваться любым человеком, прошедшим соответствующее обучение, в том числе для разрешения или предотвращения спора и разногласий, в которых он выступает одной из сторон».

Именно созданный на основе медиативного подхода метод школьной медиации в настоящее время стал основой работы значительного количества служб медиации, созданных в настоящее время во всех регионах страны. В рамках этой технологии в настоящее время работают около 80 тысяч школьных медиаторов в более чем 25 тысячах служб школьной медиации [7].

Ряд исследователей справедливо усматривают в медиативном подходе дальнейшее развитие концепции деятельностного подхода, разработанного в трудах классиков российской психологии С.Л. Рубинштейна, А.Н. Леонтьева, П.Я. Гальперина [8], что позволяет интерпретировать его как новую технологию проектной деятельности, результатом которой как раз и может стать смена парадигмы развития российского социума в желаемом направлении медиационного развития. Основой такого развития может стать теория медиации классика отечественной гуманитаристики А.С. Ахиезера, 90-летие которого недавно отметила российская научная общественность [9]. Теоретические разработки А.С. Ахиезера, В.С. Библера, В.А. Лекторского, А.В. Тихонова, Г.Л. Тульчинского и ряда других исследователей, разработанная 


\section{ОБРАЗОВАТЕЛЬНЫЕ ТЕХНОЛОГИИ \\ В СОВРЕМЕННОМ УЧЕБНО-ВОСПИТАТЕЛЬНОМ ПРОСТРАНСТВЕ}

А.П. Давыдовым методология социокультурного анализа позволяют выявить логику и структуру медиационных процессов как основания и механизмов развития общества [10].

Для преодоления «институциональных ловушек» и «эффекта колеи» (термины А.А. Аузана), определения перспективных траекторий развития медиации как эффективной технологии целесообразным представляется как можно более широкое внедрение в практику обучения и воспитания медиативного подхода, основы которого были разработаны Ц.А. Шамликашвили [11].

Таким образом, база для постепенного изменения социокультурной парадигмы развития российского социума на основе медиации и медиативного подхода уже имеется. Теперь необходима настойчивая и планомерная работа, рассчитанная на достаточно длительную перспективу, как и все образовательные технологии.

По мнению Ц.А. Шамликашвили, разделяемого нами, «модули о медиации, носящие ознакомительно-информационный характер, должны быть интегрированы на всех уровнях системы общего и специального образования, а также высшей школы. Медиативный подход должен стать частью магистерских программ, программ дополнительного образования взрослых, повышения квалификации, переподготовки. Также медиация и медиативный подход должны стать частью системы непрерывного образования взрослых, в том числе в условиях старения населения, с целью сохранения социальной востребованности людей пенсионного возраста. Медиативный подход является залогом сохранения и развития человеческого потенциала в современных условиях, развивая культуру общения, диалога, договороспособности в каждом человеке и менталитет сотрудничества в обществе в целом» [11, с. 23].

Не менее важной задачей является исследовательская деятельность по дальнейшему развитию теоретической и методологической базы для внедряемых медиативных технологий как в сфере школьной медиации, так и в восстановительных практиках. Учитывая перечисленные выше теоретические направления исследований, очевидно, что эта работа является междисциплинарной и требует координации усилий специалистов в самых разных областях гуманитарного знания. 


\section{Список литературы}

1. Приказ Министерства образования и науки Российской Федерации (Минобрнауки России) от 14 февраля 2011 г. № 187 г. Москва «Об утверждении программы подготовки медиаторов» // 23 марта 2011 г. Российская газета - Федеральный выпуск № 60(5436). — https://rg.ru/2011/03/ 23/mediacia-dok.html

2. Профессиональный стандарт «Специалист в области медиации (медиатор)». Утвержден приказом Министерства труда и социальной защиты Российской Федерации от 15 декабря 2014 г. № 1041н // Третейский суд. - 2015. - № 2/3 (98/99). - С. 75-88.

3. Яковлев В.Ф. Закон свободного примирения // Медиация и право. 2006. - № 1. - С. 14-16.

4. Альтернативное разрешение споров: Учебник / под ред. Е.А. Борисовой. М.: Городец, 2019. - 416 с.

5. Вечерина О. П., Путалова И. Б. Структура российского института медиации: настоящее, прошлое, будущее // Юридические исследования. - 2020. - № 9. - C. 47-63. DOI: 10.25136/2409-7136.2020.9.34287.

6. Вечерина О.П., Путалова И.Б. - Проблемы профессиональной подготовки медиаторов в России // Современное образование. - 2021. - № 1. C. 1-13. - DOI: 10.25136/2409-8736.2021.1.34746.

7. Всероссийское совещание школьных служб примирения и медиации : Сборник материалов / под ред. Н. В. Горлийчука. - М.: ФГБУ «Центр защиты прав и интересов детей», 2020. - 433 с.

8. Рождествина А.А., Железовская Г.И. О некоторых аспектах содержания понятия «медиативный подход» // Изв. Сарат. ун-та. Нов. сер. Сер. Философия. Психология. Педагогика. - 2017. - Т. 17. - Вып. 4. - С. 489-493.

9. Теория медиации Александра Ахиезера. Воспоминания. Библиография. - М.: Новый хронограф, 2019. - С. 83-124.

10. Давыдов А.П. Основание развития как социокультурная проблема (к вопросу о медиационной теории эволюции западного социума) // Вестник Института социологии. - 2018. - № 24. - С. 27-51.

11. Шамликашвили Ц.А. Медиативный подход и его возможности в развитии человеческого капитала и совершенствовании общественных отношений // Вестник Федерального института медиации. - 2017. - № 3. C.10-25. 